\title{
O azarado Macunaíma ${ }^{1}$
}

\section{PRISCILA FIGUEIREDO ${ }^{I}$}

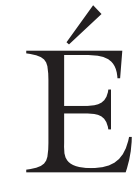

UMA CALAMIDADE o final de Macunaima, com o herói estropiado como um lazarento, sem perna e muiraquitã, não vendo mais graça nesta vida e solitário como um "defunto sem choro" depois que tudo à sua volta tinha se transformado em pedra e silêncio, por ação sua, inclusive. E, mesmo depois de subir ao céu, agarrado num cipó que semeou com esse propósito, ainda precisou ir amolar alguns ilustres moradores celestiais e então aguentar bateção de porta na cara e a humilhação repetida de o mandarem ir tomar banho. $\mathrm{O}$ desamparo parecia não ter fim. De fato, como bem tinha diagnosticado e concluído pouco antes de deixar a Terra, “quando urubu está de caipora o de baixo caga no de cima, este mundo não tem jeito mais e vou pro céu” -, sua má sorte viera para ficar, inaugurava um novo tempo para ele e ainda por cima ganhava dimensão interestelar. A inhaca - como se tivesse sido produzida por uma macumba das boas, que ele mesmo tentara fazer em certa ocasião para seu grande inimigo - mais se confirmou quando o único disposto a acolhê-lo em sua maloca precisou recusá-lo, pois, como este explicou dentro daquele espírito sincrético tão característico do livro: “Chegaste tarde, herói! Já somos em doze e com você a gente ficava treze na mesa. Sinto muito mas chorar não posso". Um pequeno gesto, porém, da parte do supersticioso anfitrião resolveu, como que musicalmente, o que parecia uma desdita sem remissão, pois, por pena daquele saci sem abrigo, a quem no entanto devia um favor, "virou Macunaíma com todo o estenderete dele, galo galinha gaiola revólver relógio, numa constelação nova", a Ursa Maior. ${ }^{2}$ Fazia isso por pena e gratidão, mas também por reconhecimento à importante estirpe daquele único remanescente de todo um povo, "descendente de jaboti, raça primeira de todas". E Macunaíma então sossegou, transformado naquele famoso "brilho inútil das estrelas" e interrompendo toda a agitação que fora a substância da rapsódia.

O "herói de nossa gente", longe de ser um indivíduo - ou mesmo um protoindivíduo - no sentido moderno do termo, e marcado, conforme prenunciava o "nenhum caráter" do subtítulo, por uma grande instabilidade em vários níveis, raça, classe, psicologia, moralidade, grau de maturação física e mental e, em certa ocasião, até mesmo sexualidade ${ }^{3}-$, sintetizaria a identidade, embora fugidia, do brasileiro. ${ }^{4}$ De fato, essa "essência" parece ter sido apreendida e elaborada em profundidade pelo método compositivo peculiar do livro, que certamente fez os documentos preexistentes de que se valeu - orais, como os relatos indígenas registrados por Koch Grünberg, ou escritos, como a literatura de viajantes, eruditos ou populares, de matriz ibérica, africana, ameríndia ou mestiça - liberar e intensificar a "alma da matéria" que sua experiência, a sensibilidade com a 
vida popular e o estudo disciplinado do rico acervo de suas criações já vinham captando. Mas este não apenas o instruiu sobre técnicas de formalização ou a noção de certas estruturas repetitivas de "caráter" - que, como se sabe, deve ser compreendido num sentido não apenas moral, mas também à luz da reflexão a esse respeito presente no Ensaio sobre a música brasileira. Na verdade, esse conjunto de documentos e suas muitas variantes foi ele mesmo compor, com pedaços do seu corpo, o corpo do romance. Se, como destacou Gilda de Mello e Souza em $O$ tupi e o alaúde, era patente aí, como nunca o omitiu Mário de Andrade, o uso de um método "parasitário", dependente de "outros sistemas imaginários, voltados para si mesmos", ${ }^{5}$ nem por isso se desativava a dimensão do sujeito criador ou singularidade autoral. Não obstante, ponderava, "a originalidade estrutural de Macunaima deriva [...] do livro não se basear na mímesis, isto é, na dependência constante que a arte estabelece entre o mundo objetivo e a ficção [...]". ${ }^{6}$ Como se trata de uma breve observação, sem maior desdobramento, e como o segundo estudo do livro traz elementos importantes que nos permitem pensar justamente na relação da obra com a empiria (como a percepção de antinomias estruturais que atravessam o romance - p. ex., a de ócio e trabalho), e como, ainda, a advertência pode supor não uma recusa da estilização de processos reais, mas antes uma ênfase no fato de que a obra não se constitui em princípio ex-nibilo, à maneira do que ocorre em certa tradição literária, gostaria antes de aproveitar a ressalva como um estímulo para refletir de que modo, apesar do "parasitismo" constitutivo do processo criador da rapsódia, seria possível apreender nesta uma certa experiência histórico-social, o que nos obrigaria, portanto, a enfatizar a ideia de mimese. Talvez fosse o caso de perguntar se, embora sobrecarregada de mediações, as operações de que se valeu a racionalidade subjetiva para selecionar, modificar, colorir ou desfigurar, articular ou desarticular fragmentos, assim como o esforço em enxertar, suprimir, deslocar, enfatizar, multiplicar ou obliterar algumas determinações ou nuances no interior dos próprios fragmentos, não teriam se dado de forma a exprimir um ritmo ou processo sem dúvida objetivo e intuído pelo autor.

O gesto por assim dizer coreográfico que articula as sequências (algo como a forma suite $^{7}$ ) manteria as partes vibrando isoladas em sua especificidade. A unidade inacabada permitiria que a multiplicidade sensível dos diversos fragmentos se manifestasse, e isso não se daria sem perturbação do sentido. ${ }^{8}$ De certo modo, essa unidade depende da legislação da linguagem, ou de uma "inteligência estrutural", como diria Haroldo de Campos, que via em Macunaíma um "dique" ao que constituía "a debilidade principal da teoria como da prática marioandradina", isto é, o psicologismo. ${ }^{9}$ No entanto a objetividade, fetichizada pelo crítico e incontrastada pela ausência de uma noção mais forte de subjetividade, se empobrecia de determinações ao ser meramente identificada ao esquema morfológico adotado, em que os fenômenos eram sacrificados sob certo número de elementos invariantes. Mesmo na esteira da morfologia proppiana seria possível chegar a uma objetividade menos pálida, ou abstratamente univer- 
sal, pois o próprio formalista russo não desconhecia as raizes históricas do conto de fadas, título de uma obra sua e referência central para o método indiciário de pesquisa de um historiador como Carlo Guinzburg, por exemplo. ${ }^{10}$ Como se fosse fiel a uma divisa que também seria a de Ionesco - "só as palavras importam, o resto é tagarelice" -, Mário de Andrade permitiu que emergissem experiências tantas vezes inexpressas ou emudecidas e conformou o personagem principal como uma espécie de cavalo de santo através do qual deixou falar os idioletos e idiomas pátrios em toda a sua variedade geográfica e histórica, popular e erudita. Provérbios, locuções, frases feitas, mesmo os de sentido mais discordante entre si - como ai que preguiça e quem conta história de dia cria rabo de cotia, um provérbio para prevenir preguiçosos -, assim como antigas fórmulas de invocação, frases atribuídas a personagens históricos, causos, parlendas, narrativas etiológicas etc. descem no herói para falar os sujeitos que já não os falam. Quando, ao acabar de ser informado por Vei que por um mau passo deixara escapar por entre os dedos nada menos que a distinção de um casamento nobre e a eterna juventude (casava com uma das minhas filhas e havia de ser sempre moço e bunitão), além do prêmio triplo, já prometido, Oropa, França e Babia, Macunaíma responde de forma a mais marota $A h$ si eu subesse!, com a prosódia regional quase mimeticamente fixada pela grafia, e, depois, mais uma vez provocado, acrescenta, dando de ombros, Pois nem eu queria nenhuma das três [filhas de Vei], sabe? Três, diabo fez ${ }^{11}$ - quando assim Macunaíma fala, ou quando tais frases falam através dele, o que de fato relampeja, provocando em nós a mais profunda ternura, é o estranho desacordo entre o futuro grandioso retirado do horizonte e a maldisfarçada indiferença ("Ah si eu subesse!"), em seguida abalada, daqueles que, tão logo são avisados de tudo que podiam ter desejado e alcançado, não conseguem avaliar o que perderam porque de fato nunca se tinham imaginado com direito a tal desejo. É o cúmulo do azar: perder por um triz a felicidade que não fora nem mesmo cogitada. Se o tivesse sido, talvez se pudesse ter agido com mais cautela. Não é possível dizer que as uvas são verdes quando nem mesmo existiam uvas em tal horizonte de expectativas. Nesse sentido, o "três, diabo fez" não tem exatamente o mesmo sentido aqui. Como os casos de jabuti, a fábula moral sobre o destino da raposa, ou da astúcia jactanciosa que no final se revela menos astúcia porque outros, se fazendo de mortos ou mais fracos, se saíram melhor, se é um conteúdo também presente em Macunaíma, não lhe dá o tom predominante e está subordinado a algo de maior gravidade. Macunaíma é mais azarado, e sobre ele até mesmo os urubus defecam. ${ }^{12}$ Num caiporismo dessa ordem, falar em autodeterminação e liberdade é um escárnio. Assim, da mesma forma que "Ah si eu subesse", outras construções linguísticas também podem revelar o seu segredo, que vemos fulgurar como o tesouro escondido numa caverna, aberta mediante algum abre-te, sésamo. Se muitos fragmentos são despertados de seu sono, se voltam a se colorir e então exprimem o mais sonoro, articulado e vivo, às vezes sob uma única frase, um único gesto, como os mortos em nossos sonhos, logo também, como estes, se retiram ou voltam 
a adormecer - no ambiente desgeograficado e acrônico do livro tudo pode se tornar paisagem e silêncio também. Mas, como em relação a tudo que não é humano ou mesmo é tão somente matéria inorgânica, a frase "[isso] já foi gente um dia que nem nós” tem algo de uma promessa de desencantamento, ou nova metamorfose, esta redentora, pela qual se recuperaria a essência humana antes de sua petrificação ou "aprisionamento" em paisagem ou bicho. Em certo sentido, chamando a atenção para o fato de que todos os entes já foram humanos como nós, clama-se para um olhar e um ouvido que lhes seja permanentemente atentos - pois, em algum momento, sem que estejamos esperando, podem nos contar toda sua história e sofrimento, como a cascata Naipi.

Mergulhados no mesmo fluido, o fragmento (autoral ou anônimo), por muito distante que tenha sido sua criação no tempo, se torna atual, e o muito próximo se torna remoto. O conteúdo de um e outro é liberado aproximativamente, por ressonâncias - como "cabeças mortas" dos materiais justapostos. ${ }^{13}$ Do mesmo modo, no nível das imagens, também o muito próximo, o mais contemporâneo, nos remete ao mais longínquo, e vice-versa: a fumaça despedida pelas chaminés industriais em decorrência da metamorfose química pode subitamente revelar parentesco com a fumaça de calcinações antropofágicas, ou o maquinismo de um ascensor pode aparecer como pré-histórica astúcia concentrada, o sagui afoito por escalar, permitindo entrever no impulso deste em vencer a natureza um antecedente do elevador. $\mathrm{O}$ carro é uma onça congelada em fuga; na fuga, ou mesmo na sanha persecutória da onça, cintilará a potencialidade de um automóvel de quatro patas. O irmão Maanape é transformado em telefone, tão feiticeiro quanto aquele quando traz para nossa vizinhança o que de fato continuaria afastado - no assombro modernista com o telefone, este frequentemente aparece sob uma aura mágica ou animista, como no romance de Proust e no Castelo de Kafka.

Abrindo a perspectiva narrativa para o pensamento mítico, as analogias se reproduzem umas atrás das outras, e tudo que está na cultura dispõe de um equivalente na natureza, assim como todo ente natural tem um equivalente na cultura, ou uma expressão morfológica mais acabada. Quando se chega a São Paulo, elos complexos e modernos são trocados nos miúdos mais concretos da vida selvagem. Mas essa troca, por outro lado, não dá conta de todas as determinações do objeto original, com perda de abstração e generalização. A rapsódia - em que as metamorfoses funcionam como um verdadeiro maquinismo, uma força produtiva que multiplica imagens - é atravessada por cortejos e cortejos de substantivos concretos, mas fundamentalmente de bichos, plantas, entes fabulosos, acidentes geográficos, danças tribais, doenças, nomes de embarcações primitivas. Como escreveu Marx, não se "produzem as abstrações mais gerais [mais complexas] senão onde existe o desenvolvimento concreto mais rico [...]". ${ }^{14}$ Macunaima é colorido como um mosaico, "um viveiro de imagens", 15 prenhe de coisas, e as enumerações muitas vezes tomam a dianteira em relação à ação, tiram desta o protagonismo e nos dispersam quando passam em desfile nas ruas 
do texto; mas essas coisas exibidas, próprias a um mercado primário, ainda não formam uma série infinita. ${ }^{16}$ Sua quantidade imensa, porém - quantidade que aumenta com a decomposição de produtos culturais complexos em entes naturais, de artefatos e coisas em corpos orgânicos - ainda não foi suficiente para que se atingisse um nível mais complexo de abstração. O dinheiro nesse contexto dificilmente aparece como a unidade mais abstrata de equivalente geral, e sim sob determinações mais fracas, metais, bagos de cacau. Em certo momento, a moeda de prata é brandida de longe, como uma miragem vindo de uma etapa historicamente anterior do processo evolutivo da forma dinheiro: aquelas que um gambá defecaria e na verdade tinham sido prometidas por um típico conto de mascate. Além disso, dão em árvores certos artefatos, como os whiskies e as garruchas, quando não derivam de operações fetichistas, como o telefone, já mencionado. Todos estes só seriam produzidos por meio de trabalho, morto e vivo, e, portanto, na qualidade de "corpo de valor" ou "substância de tempo de trabalho" que também são, dificilmente seriam adquiridos sem que esse valor pudesse se expressar, ou seja, na relação mercantil. Em suma, não vemos os heróis e os manos indo ao comércio ou labutando, não os vemos na circulação ou na produção, transformando sua força de trabalho em mercadoria, ainda que seu dispêndio de energia seja enorme e Macunaíma desde criancinha procure dinheiro enterrado ou viva dandando "pra ganhar vintém"; 17 do mesmo modo, referência a dinheiro-moeda propriamente não há - a não ser pelo rápido exemplo invocado. O ar de "país da Cocanha", evidente em alguns momentos, não nos deve iludir porque em todo caso sentimos o quanto o eixo de sua existência é a velha luta pela vida, onde quer que estejam, no Sul ou no Norte, em São Paulo ou no fundo da mata, esta frequentemente assolada pela escassez (afora o momento mais pleno de sua vida, erótica e materialmente, quando Imperador, casado com Ci). Não é apenas para agravar a sua situação e convencer as amazonas a lhe mandarem "dinheiro" que aparece, na Carta, tão espantado com a variedade de coisas nunca imaginadas a que a existência em São Paulo o obriga a adquirir, "máquinas" como meia-calça, carro, bonde, aluguel, e tudo o mais que à primeira vista excederia a estrita necessidade, os meros peixes e macaxeira indígenas, mas acabariam por se tornar também necessidade ou "segunda natureza". O progresso técnico é realmente admirável e emancipador, desde que não continue a série mítica de sacrifícios humanos, e desde que se possa fruir dele; no entanto, a trinca de manos passa um cortado quando a vida na cidade grande parece ser quase impossível sem ele, que não está a seu dispor como favas contadas. Mal sabemos como eles se viram pra pagar o quarto na pensãozinha da rua das Palmeiras ${ }^{18}-\mathrm{e}$, em certo momento, provavelmente já tocado pelo sonho de fugir do aluguel, o irmão mais novo e mais preguiçoso subitamente os convida para a aventura da autoconstrução, "erguer um papiri". ${ }^{19}$ Não sabemos como ele faz pra se virar, mas ele dá um jeito, como bom malandro que não deixa de figurar e frequentaria até o célebre terreiro da tia Ciata no Rio, onde, ao que o narrador indica, deve ter topado com Pixinguinha e Bandeira. E haja macumba 
e metamorfose mágica para Maanape compensar aquelas metamorfoses e saltos mortais, também um tanto mágicos, próprios à sociedade em que se generaliza a forma mercantil e o trabalho abstrato, nas quais estão impossibilitados de participar e sofrer, ao menos plenamente, e são descritas por Marx em linguagem tão alegórica.

Fome e sexo de fato movem a máquina de Macunaíma, mas o mal-estar de sua civilização certamente não deriva de renúncia instintual. Que há certa espécie de mal-estar, porém, é inequívoco; por outro lado, também não é certo que ele exista apenas porque nã houve repressão libidinal. Extrair do romance algo como uma concepção da história nos permitiria talvez precisar melhor a natureza desse mal-estar, mas isso também não se deduz de forma imediata. Podemos começar com a impressão deixada pelas páginas finais, dominadas pelo que se nomeia em certa altura como tangolo mangolo, isto é, uma corrente interminável de azares ou infortúnios: ela indicaria que não predomina, no balanço geral, uma relação entusiasmada com a noção de progresso. ${ }^{20}$ Mário parece ter intuído algo muito brasileiro de fato, e me parece que intuiu mais no que concerne aos "eternamente" azarados, ou seja, aos pobres, aos retirantes, aos selvagens desenraizados, ao sem eira nem beira, àquela vasta galeria que Caio Prado Jr. chamou de "inorgânico" e só pôde concebê-lo conforme uma rica tipologia, com variações regionais, porque, como lembrou Antonio Candido numa pequena digressão sentimental memorável e com o título significativo de "A força do concreto", era um historiador-geógrafo. ${ }^{21}$ Como Mário, especialmente depois (e não antes) de escrever a primeira versão de Macunaima - que não obstante atualizava e comprimia numa só narrativa o projeto de romance extensivo de José de Alencar, de apanhar o país nos variados graus de sua existência histórica e primitiva ${ }^{22}$-, Caio Prado Jr. também foi medir o Brasil com os palmos do próprio corpo e a concha de seu Volks, metendo-se em grotões, brenhas e "quebradas", lá onde o espaço é mais visivelmente tempo congelado. De maneira análoga à do herói e Mário (e da Coluna Prestes, podíamos acrescentar...), ele deve ter deparado, em suas andanças motorizadas, com muitos espectros do Brasil primitivo, como a mãe de Macunaíma, uma índia tapanhumas, com remanescentes de arekunás e taulipangues, mas também com aqueles que, produzidos pela sociedade colonial e pós-colonial, zanzavam em desterro permanente: índios empregados na construção de ferrovias, negros forros centenários, pardos, tapuias, quilombolas, ribeirinhos, jagunços, cangaceiros, moradores e agregados de engenho, sitiantes caipiras, parceiros, beatos paupérrimos e proféticos etc. ${ }^{23}$ Trata-se da "classe" que sempre mais sentiu as repercussões de uma evolução "por arrancos, por ciclos em que se alternam, no tempo e no espaço, de prosperidade e ruína [...]" ${ }^{24}$ A cada ciclo econômico descendente, um pedaço da estrutura colonial se desarticulava, atingida pela crise, e "um número mais ou menos avultado de indivíduos inutiliza-se, perde suas raízes e base vital de subsistência". Macunaíma parece pertencer a essa população que desde a Colônia se desenvolveu à margem da escravidão, embora como um derivado seu 
e no qual, diferentemente dela, a "inorganização" é dominante: "Para esse setor não se pode nem ao menos falar em 'estrutura social' porque é a instabilidade e incoerência que a caracterizam, tendendo em todos os casos para estas formas extremas de desagregação social, tão salientes e características da vida brasileira [...]: a vadiagem e a caboclização". De tal desarticulação, o presente, como um processo histórico dilatado que se constituíra com o fim da colonização, ainda oferecia um testemunho vivo:

Salvo em alguns setores do país, ainda conservam nossas relações sociais, em particular as de classe, um acentuado cunho colonial. [...] Quem percorre o Brasil de hoje fica muitas vezes surpreendido com aspectos que imagina existirem nos nossos dias unicamente em livros de história; e se atentar um pouco para eles, verá que traduzem fatos profundos e não são apenas reminiscências anacrônicas. ${ }^{25}$

Em nota lembrava a observação de um amigo estrangeiro, que dizia invejar os historiadores brasileiros que "podiam assistir pessoalmente às cenas mais vivas do seu passado", 26 "em parte modificado", mas inequivocamente se prolongando até o presente - do que dava testemunho a organização incompleta do trabalho livre no país. Naquela altura em que escrevia, às vésperas da Consolidação da Leis do Trabalho (ou melhor, de alguns setores do trabalho na cidade, com exclusão de todo o setor rural), "se havia um processo de ajustamento em pleno vigor", conservava não obstante traços bastante vivos do regime escravista que o precedeu". Por fim, “os problemas brasileiros de hoje, os fundamentais, pode-se dizer que já estavam definidos e postos em equação há 150 anos", 27 quando já se evidenciava a "falta de nexo moral que define a vida brasileira" no início do século XIX e a "pobreza de seus vínculos sociais". ${ }^{28} \mathrm{O}$ desvalimento de parte substantiva da população, que vivia (?) assim da mão para a boca - quando mesmo esse processo não se interrompia no meio do caminho e se reduzia a fome e miséria -, impossibilitada de pensar no dia seguinte, está evocado por Macunaíma e supera eventuais determinações discordantes nos materiais de que é feito. ${ }^{29}$

Apesar dos esforços formativos de Mário de Andrade em relação à cultura nacional (que nos anos 1930 ganharia nova dimensão no âmbito da política institucional) e de seu fascínio pelo ethos burguês do trabalho, ausência que paira como sombra no romance, ${ }^{30}$ como já sublinhou Gilda, esse fascínio sempre estivera em relação tensa ou antinômica com a sua ainda mais adorável "divina preguiça", não porque a praticasse muito (é bem provável que não pela sua tendência infatigável), mas porque a reconhecesse como um valor das "civilizações solares", como dizia, e, penso, como um elemento da "vida inorgânica" que buscava positivar. Anos antes já a tinha defendido contra aqueles que, apoiados na psiquiatria, vinham classificá-la como estado patológico - "Revoltemo-nos!", dizia, pois a preguiça, prezada pelos deuses, a civilização helênica e romana, assim como pela arte e a poesia, não podia ser qualificada de mórbida, decaída 
até mesmo na dignidade de pecado mortal. Vicioso, sim, seria o "far niente burguês". ${ }^{31}$ Pode-se, no entanto, lembrar momentos, como o do arrependimento do herói pelo seu "se deixar viver", por não ter conduzido a vida de acordo com um projeto (um desígnio racional) ou pelo trabalho, ao qual se alude rapidamente pelo exemplo prototípico da cidade de Pedra, em Alagoas, a vila operária de Delmiro Gouveia, "nortista" como ele, que a concebera no sertão de Alagoas - próxima à fábrica de linhas e à usina hidrelétrica que mandara construir, entre outros melhoramentos - de modo a adestrar e disciplinar o espírito e o corpo para a vida laboriosa, reatualizando um processo de adestramento análogo ao dos primórdios da Revolução Industrial. ${ }^{32} \mathrm{~A}$ ambição do projeto, cujo ímpeto civilizatório inequívoco, concentrado numa só pessoa, tem uma violência que cabe especificar em relação àquela subjacente em todo processo civilizador. $\mathrm{Na}$ luta por impor um "mecanismo urbano" sem igual no país, lembrou Mário numa crônica de 1928, ele não hesitaria em usar o chicote, muito pessoal, de um domador de circo (Fellini se esbaldaria em dar representação à figura), embora menos letal que o de um coronel, ${ }^{33} \mathrm{o}$ que não era pouco. No projeto, ambição pessoal e sentido de missão, inclusive o de criar mercado interno. Conforme a defesa do escritor, que talvez sentisse ser no âmbito da cultura um equivalente de Delmiro, esse "Antonio Conselheiro do trabalho não mandou matar ninguém". Em todos os momentos em que mencionou o cearense que começara muito pobre e, fiel à religião do trabalho, como enfatizava num de seus artigos na imprensa de Recife, construíra um pequeno império no sertão e morria assassinado em 1917, ao que tudo indicava, por contrariar interesses de oligarquias locais e de trustes estrangeiros, Mário o fazia com grande admiração - por esse que também qualificou como "gênio da disciplina" e "dramático movimentador das luzes, luzes verdes de esperança, luzes vermelhas de alarma dentro do noturno de caráter do Brasil". De fato, o empresário materializou em seu tempo e em nível regional um desses esforços desenvolvimentistas titânicos, que também irrompem como surtos em nossa modernização, buscando furiosamente fazer o país avançar 50 anos em 5, conforme o intento de Visconde de Mauá, a quem foi comparado, e de Juscelino Kubitschek, que explicitaria a divisa. Tais figuras poderiam tranquilamente ser incluídas entre as fantasmagorias de Macunaima. Ainda assim, não me parece, contudo, que a ausência de esforço empreendedor, ética burguesa do trabalho ou que quer que fosse nesse sentido, refletida na tela da (má) consciência do herói por dois momentos, efetivamente explique as calamidades que lhe sobrevêm depois. No momento, aliás, em que o personagem, com o "beicinho tremendo", faz um caborge e transforma a cidade paulista num "bicho preguiça todinho em pedra", depois de lamentar o estado de coisas pelo qual "muita saúva e pouca saúde os males do Brasil são", ${ }^{34}$ podíamos dizer que ele de fato cai em si, entrando numa disposição melancólica até então ausente e na verdade espantosa - quase um erro de verossimilhança interna. Em todo caso, o descendente de Jabuti finalmente perdia aquela inocência que para Nietzsche seria própria do animal, o qual é feliz porque não pesa sobre ele a imagem 
do passado, ou a percepção deste como um "ter sido sem fim". Ele antes acedia àquele "grau de insônia, de ruminação, de sentido histórico, no qual todo vivente se degrada e por fim sucumbe, seja ele um homem, um animal, um povo, uma cultura". ${ }^{35}$ Agora uma súbita e inverossímil má-consciência vinha tomar o herói originalmente de extração fabular, plástico e mutável como pura energia libidinal, e no qual até então não parecia haver superego - em suma, um modo de ser que parecia a estilização do próprio "mundo sem culpa". ${ }^{36}$ Sem prejuízo de que era Mário que devia estar chorando através de Macunaíma, tratava de realçar de todo modo uma outra etapa no processo evolutivo do "Espírito" nacional, etapa que não se alcançaria sem a experiência na cidade bandeirante, em que a modernização econômica ia mais avançada. Contrariando expectativas iluministas, no entanto, a verdade é que a perda de inocência do herói com a tomada de consciência do passado, momento inaugural de sua autocompreensão, não lhe serviria de nada (como veremos melhor mais adiante), nem mesmo viria interromper aquela compulsão à repetição que o tinha caracterizado desde o início. Ele precisamente se situava no limbo apontado por Nietzsche em que a visão da totalidade histórica, a iluminação de tudo o que foi, porque não podia ser "usada em prol da vida", não garantiria por si só um futuro melhor, tão esperado com o resgate do amuleto, o qual não deixava de ser também um elo de memória comunitária.

Contemporaneamente a Macunaima, naqueles mesmos anos 1920, a ideia de que o conbecimento da verdade na história levaria à sua superação era do mesmo modo desmentida pela psicanálise - sobretudo pela formulação conceitual da ideia de repetição vinculada ao conceito de pulsão de morte - e pela "ideia de uma história natural" que permeava alguns esforços da nascente Escola de Frankfurt e já estabelecia as bases para a tese da "dialética da Aufklärung", a reversibilidade da razão em mito, a ser desenvolvida por Adorno e Horkheimer nos anos 1940. Isso para mencionar exemplos apenas daquela crítica ao progresso que ocorria no interior de tendências sem dúvida racionalistas. No contexto do entreguerras, de consolidação do capitalismo monopolista e a consequente crise da democracia liberal, essa crítica à razão iluminista também formava um dos interesses de um romance como A montanha mágica, de Thomas Mann, por exemplo, de cujas páginas finais, aliás, não se extrai aquela confiança na racionalidade do real e no trajeto da humanidade em direção à sua libertação, noção que, se nos momentos mais dignos, como lembrou Adorno, não foi indiferente à carnificina produzida a cada etapa histórica, não deixaria de lhe restituir um sentido no interior do que constitui o próprio processo teleológico de evolução da Consciência - para remeter àquela filosofia em que essa concepção tem seu maior nível de acabamento, a filosofia de Hegel, herdeiro da Ilustração. Quase tão contemporânea do esquema hegeliano, no entanto, se desenvolveu outra perspectiva, crítica da modernidade burguesa, identificada a certas vertentes do romantismo (reacionárias, inclusive) e que, como filosofia cíclica da história, viria a ser especialmente reatualizada em momentos de crise. ${ }^{37}$ Como um derivado 
dela, o "discurso do organismo", que se poderia fazer remontar até Herder (e mesmo até Vico, se se sair da tradição alemã ${ }^{38}$ ) e, com diferenças que eu pouco saberia especificar, ganharia novos desdobramentos na filosofia da identidade de Schelling, em Novalis, na teoria morfológica de Goethe, em Schopenhauer, no conceito nietzschiano de vida, no monismo de Haeckel (entre nós bastante divulgado pela Escola do Recife), em Dilthey e, na virada do século, na obra de pensadores tão diversos como Simmel, Bergson e Spengler. ${ }^{39}$

Talvez a análise de Macunaima não devesse descartar de todo a ideia de morfologia como repetição estrutural. Anos depois de Haroldo de Campos, outro comentador viria levantar a lebre, agora não por via da obra de Propp, mas do Declínio do Ocidente de Spengler, o qual, do mesmo modo como o teórico russo, também atribuía a paternidade de seu método à teoria de Goethe sobre as metamorfoses das plantas. Berriel observou o quanto a equiparação morfológica entre o desterrado habitante da cidade moderna, migrando entre alojamentos funcionais, e o nômade proto-histórico é uma das visões que devem ter interessado ao autor e a tantos outros modernistas, conforme sugerira Menotti del Picchia. ${ }^{40}$ "A imagem do novo primitivo" também fisgou Adorno, que, em conferência sobre o autor da "morfologia da história universal", no final dos anos 1930, realçava como este, depois de um grande sucesso popular - que, aliás, acabou por nos alcançar e ressoar para além dos anos 1920 e do primeiro modernismo - e por um conjunto de razões - como a estabilização da inflação, fazendo que "ninguém na Alemanha quisesse saber da tese do declínio"-, caíra no esquecimento com a mesma rapidez da catástrofe que anunciava para o mundo em sua teoria, cuja primeira parte fora publicada pouco antes dos anos 1920. Spengler teria percebido com um "atento olhar de caçador [...] as cidades da humanidade como se estas fossem regiões selvagens, o que elas são" ${ }^{41}$ O que elas são - trata-se de algo com que ele está de acordo, razão por que resgata, em meio à Segunda Guerra Mundial, não apenas a "fisiognomonia da metrópole" traçada por Spengler, repassada de tremores arcaicos, e conforme a qual as casas, abandonadas pelos deuses Lares, teriam regredido a acampamentos na paisagem petrificada sob o progresso técnico, tão inorgânica quanto a unidade inorgânica do dinheiro. ${ }^{42}$ Também reabilitava o prognóstico de uma crescente concentração de poder em direção ao que chamava de "cesarismo" e, em vista disso, concluía: "Por isso a história parece extinta. [...] os acontecimentos se passam entre os oligarcas e os seus especialistas em assassinatos, não se originando mais da dinâmica da sociedade [...]". ${ }^{43}$ Mas a recuperação de um autor cujo elogio das forças vitais e desprezo à economia e ao dinheiro ${ }^{44}$ acabariam por encontrar expressão política no nazismo, se dá, na verdade, dentro de um interesse de grupo por aqueles "teóricos do conservadorismo reacionário cuja crítica ao liberalismo mostra-se em muitos pontos superior à crítica progressista": 45

[...] a rejeição da história como progresso se tornou um tema crescentemente dominante em seus escritos depois da eclosão da Segunda Guerra [...]. Deve-se a isso o fato de que Adorno pôde encontrar um momento de vali- 
dade na análise de Spengler do declínio do Ocidente, bem como o fascínio continuado de Horkheimer por Schopenhauer e a aderência de Benjamin ao motivo do Velho Testamento que situava na Queda a origem da história. No entanto, seria completamente equivocado estabelecer uma afinidade entre a visão que estes têm da história e a concepção encontrada no judaísmo, em Schopenhauer e em Spengler. Pois uma coisa era sublinhar a irracionalidade e a destrutividade na história, outra, bem diferente, era alçar as deficiências da história ao nível de verdade ontológica. Adorno e seus colegas não viam a irracionalidade como "natural" e, portanto, eterna. Eles não a consideravam mais essência da realidade do que consideravam a razão. Porque fazer isso teria sido substituir o mito do progresso histórico por uma concepção igualmente mítica de uma "natureza" constante. ${ }^{46}$

Qual o fundamento prático pressuposto no círculo mágico da morfologia de Macunaima? Qual dívida, não liquidada, está sempre a ser cobrada, como um dos monstros que o acossam para reaver parte da perna - carne de minha carne! - que, a seu chamado, fala de dentro da barriga do herói? Estou aqui, aguardando ser resgatada desse cativeiro. Na constelação da prosa, os pedaços falam, lançam apelos de seu lugar longínquo, que pode ser o fundo de um lago no qual, talvez para sempre, se perderam, como a perna de Macunaíma. Seu azar sem fim, dinamizado nos últimos capítulos, ao qual já fizemos alusão, e que, semelhantemente a personagens de algumas narrativas judaicas, também poderia pressupor uma dívida ou queda em algum ponto longínquo na cadeia de gerações que ainda pesa sobre todos os seus descendentes - esse tremendo pé frio do herói de fato poderia fazer crer numa dívida pregressa. Alguma coisa ele ou um antepassado deve ter aprontado - e de fato apronta, como em relação a Vei - para uma tal indisposição da fortuna, mas a verdade é que a punição mítica é a mera aparência do que antes define um estado permanente de desamparo. ${ }^{47}$ Porque nesse caiporismo estão materializadas como destino as desgraceiras, socialmente produzidas, é claro, dos sem eira nem beira - muitos dos quais desenvolveram a chamada malandragem, uma técnica de viver, ou, em outros termos, a espécie de apêndice autoprotetor desenvolvido na luta pela vida e que acabou mesmo por adiar em vários casos o extermínio pelos mais fortes. Trata-se do caiporismo permanente daquele setor "inorgânico”, já mencionado, engrossado desde o fim do século XIX pelas hostes de ex-escravos inassimiláveis e impossibilitado desde a Colônia de formar com a classe proprietária aquele nexo pelo qual se podia perceber o "sentido de nossa evolução", sempre completado no mercado mundial externo. Em outros termos, um pouco mais antigos que os de Caio Prado, mas como este não isento de metáforas próprias ao "discurso do organismo": é o vasto grupo impossibilitado de ser parasitado por aquela classe, como diria Manoel Bonfim, que se valeu de uma teoria biológica do crime para explicar e precisar, com certo gosto pela fenomenologia, não o crime das classes ditas perigosas, as classes populares, mas o das elites nacionais (ou melhor, sul-americanas), expresso no seu parasitismo e na produção ininterrupta de violên- 
cia, as quais compara em certa altura ao verme Chondracanthus gibbosus, cujo desenvolvimento o autor descreve de forma minuciosa, interessado no fato de que quanto mais este evoluía como parasita, como observaram os naturalistas, mais nele se atrofiavam dispositivos e aparelhos presentes no seu estado larvar. ${ }^{48}$

Muitas décadas depois do diagnóstico do parasitismo e quando se tornava evidente que o projeto desenvolvimentista democrático-popular em curso desde meados dos anos 1950 estava sendo substituído pelo desenvolvimentismo dos militares, Francisco de Oliveira observaria, em linguagem desprovida de qualquer resquício biológico, como a fração inorgânica da população, que chamava de informal, tivera na verdade papel estruturante na reprodução do "orgânico" (o uso do termo é meu) com a nova etapa do desenvolvimento capitalista no Brasil que se abria com a Revolução de 30. Mas, quando tratasse de diagnosticar, em ensaio posterior, o truncamento evolutivo do país (agora no contexto da reestruturação produtiva e do novo padrão de acumulação capitalista, globalizada e flexível), este seria indicado por uma metáfora zoográfica, ornitorrinco, ao mesmo tempo síntese, exceção e enigma da escala evolutiva darwiniana: um animal compósito, mistura de réptil e ave, fornido de órgãos de peixe e fundamentalmente mamífero, espécie de mostruário de todas as etapas históricas anteriores e, não obstante, dinamismo congelado - como a dizer, a partir daqui, não se passa mais. Embora fosse crítico da forma de realização do progresso entre nós, não descartava inteiramente tal noção. ${ }^{49}$ Em todo caso, mais uma vez a tradição de interpretação crítica do país ia buscar na natureza uma imagem para compreender as especificidades de nossa formação histórica - como as raizes de Sérgio Buarque de Hollanda, significativamente revolvidas às vésperas do Estado Novo.

Após a restituição da muiraquitã, os descalabros do passado não cessarão de se reproduzir, e, na verdade, ocorrerão em grau um pouco mais intenso e acelerado, como é próprio a todo processo de entropia, para variar um pouco a metáfora, agora emprestada da física termodinâmica. A meditação sobre o passado que faz Macunaíma, quase, poderíamos dizer, do alto de um outeiro, como um poeta romântico - mais exatamente como Macário, que contempla a cidade de São Paulo já em estado de ruína - não constitui um momento preparatório para o "qualitativamente novo", ou para a ruptura com a pura identidade.$^{50}$ Resta-lhe, no entanto, um eco de autodeterminação em "Não vim ao mundo para ser pedra". O conhecimento de si o levava antes para o exílio, como também no mesmo ano, 1926 (ou um pouco depois), se autoexilara na Bolívia a Coluna Prestes, "nem vencida nem vencedora", conforme a síntese de um de seus integrantes. Num poema escrito em 1925 e publicado em livro de 1930, "Louvação da tarde", Mário fantasiava: "[...] se acaso/ Tivesse imaginado no que dava/A Isidora, não vê que ficariam/Na expectativa pança em que fiquei!". Como explica Antonio Candido: “'Isidora' é a Revolução de 1924, chefiada pelo general Isidoro Dias Lopes, que 'deu' na guerrilha da Coluna Prestes através do sertão brasileiro até fevereiro de 1927, quando os combatentes se internaram na Bolí- 
via. 1927 foi o ano em que Mário de Andrade viajou pelo Amazonas até Iquitos, no Peru, sua única passagem fugaz e ocasional por terra estrangeira". ${ }^{11}$ Se o escritor muito provavelmente não alude ao destino da Coluna no autoexílio de Macunaíma, podemos, no entanto, vislumbrar uma afinidade estrutural entre ambas as retiradas: o conhecimento efetivo de si e do Brasil, bem como o de seus muitos tempos petrificados, parecia exigir uma nova teoria do conhecimento e quem sabe outra prática. ${ }^{52}$ Pois o herói, pela sua composição especial e sua forma de estar no tempo e no espaço, é objeto de conhecimento, o Brasil inorgânico, mas também "sujeito cognoscente" - isto é, como suporte (ou cavalo de santo, para voltar a uma imagem que já usamos) que também é, permite que se revele por meio dele um novo estágio de consciência, identificada ao autor, exatamente quando contempla por um último momento a cidade de São Paulo, o sentido irreparável do que foi e também do que não foi.

A narração dos feitos de Macunaíma só teria sido possível porque, nos revela o narrador ao fim, levara a sério a fala de um papagaio - o bicho que, quase tanto como o macaco, nos encanta pela faculdade mimética e porque gostaríamos de acreditar que nem toda a natureza permaneceu muda ou continuará a sê-lo. A voz fria e maquinal que caracteriza, no entanto, aquele que imita alheio ao que imita (aquele que justamente "papagaia") tinha retransmitido atonicamente feitos que lhe foram narrados "em viva voz" da boca de quem os praticou, do interior do que ainda era a vida pulsando, e agora, em nova transmissão e forma, fechando o sistema de informantes, voltavam a se tonificar, concentrar e recolorir. Mas o último narrador, agora humano e culto, não apenas aguçava, para melhor sentirmos, só a vida - também fixava e apurava a tendência entrópica que nela se manifestara.

\section{Notas}

l O presente texto constitui a primeira parte de um ensaio maior, "Tangolo mangolo sobre a concepção de história em Macunaíma, de Mário de Andrade”, em Ana Lisboa de Mello, Charles Monteiro, Norman Madarasz (Org.) Literatura e história - encontros contemporâneos. Porto Alegre: Gradiva, 2016.

2 "Ursa Maior", Macunaíma, o herói sem nenhum caráter (edição crítica coordenada por Telê Porto Ancona Lopez). São Paulo, 1988, p.166-7 (Col. Arquivos, Unesco).

3 Quanto à certa flutuação de gênero, pode-se lembrar o capítulo em que o herói aparece vestido de francesa com o fim de seduzir o seu antagonista, o que consegue durante um bom tempo. Embora tenha sido episódica, mostra-se o quanto pode haver instabilidade até mesmo nessa matéria. No que diz respeito à posição social, o herói em princípio (apenas em princípio) não está imediatamente identificado a uma classe específica nem a um tempo específico, ou tão somente ao domínio do "Uraricoera". Quando chega a São Paulo, instala-se numa pensão. Nesse ponto, é um pobre migrante, quando de fato levas de migrantes nortistas e nordestinos estão chegando à cidade e integram o processo em curso da "formação endógena" da força de trabalho no país (cf., Luiz Felipe de Alencastro, "A pré-revolução de 30", Novos Estudos Cebrap, n.18, 
set. 1987). Por outro lado, o personagem pode fazer discursos bacharelescos e pedir favores, seja às icamiabas, seja ao governo, por meio de um bolsa para artistas (quando então se veste à moda de um pintor-século-19 e vai à Serra da Cantareira pintar "en plein air"). Aqui a situação social brandamente sugerida já não seria a de mero migrante. Antes de chegar a São Paulo era o "Imperador do Mato Virgem", que traz consigo, em suas muitas canoas embicadas na margem do Tietê, um carregamento com toneladas de bagos de cacau, imagem em que há ressonâncias paródicas do avô do escritor, governador da Província de Goiás (cf. Gilda de Mello e Sousa, "O avô presidente", Exercício de leitura, p.100-1). Dessa perspectiva, Macunaíma é também um proprietário ou um bandeirante ou ainda um explorador exógeno, um viajante à busca do velocino de ouro, como diz na carta para as amazonas, que, aqui, pela construção paródica, nos remetem à Corte de Portugal. Parte dos bagos de cacau são comidos, mas outra é investida na Bolsa - do que derivaria uma espécie de rentismo. Voltaremos a esse ponto mais adiante, porém. Em relação aos demais aspectos, creio não haver dúvidas. Em todo caso, cf. Gilda de Mello e Souza, O tupi e o alaúde (São Paulo: Editora 34, 2003, p.38-41). Como lembra a crítica, essa flutuação semântica também caracteriza Venceslau Pietro Pietra. Em relação a esse mesmo ponto, Cavalcanti Proença já tinha usado o interessante conceito de hipodigma: "o herói é o que em Zoologia se chama hipodigma. Não tem existência real. É um tipo imaginário, no qual estão contidos todos os caracteres encontrados nos indivíduos até então conhecidos da mesma espécie.// Além dos caracteres específicos próprios, ainda se encontram nele os que o aproximam das espécies vizinhas do mesmo gênero. Macunaíma é especificamente brasileiro, porém pertence ao gênero sul-americano e se aproxima das espécie boliviano, chileno, etc. E porque é do mesmo gênero, troca a própria consciência pela de um sul-americano e se dá bem da mesma forma" (Roteiro de Macunaima, Rio de Janeiro: Civilização Brasileira, 1977, p.10). As páginas seguintes, quanto às incaracterísticas e a imoralidade do herói, também são muito interessantes e ressalta-se um elemento que, a par de tudo, não pode ser omitido: "tem gestos de uma candura esplêndida".

4 "O brasileiro não tem caráter porque não possui nem uma civilização própria nem consciência nacional" ("Prefácio à primeira edição", Macunaíma, ed. cit.).

5 Cf. Gilda de Mello e Souza, O tupi e o alaúde, 2003, p.10.

6 Ibidem. Grifo meu.

7 Segundo Gilda de Mello e Souza (2003, p.12-13), comuns tanto à música erudita como à música popular, a variação e a suíte --cujo exemplo popular mais forte estaria no bailado do bumba-meu-boi - seriam os princípios formais que teriam presidido à construção da rapsódia.

8 “Parataxis - Zur späten Lyrik Hölderlin" [ Noten zur Literatur III: Digitale Bibliothek Band 97: Theodor W. Adorno: Gesammelte Schriften].

9 Cf. Morfologia de Macunaíma, São Paulo: Perspectiva, 1973, p.60.

10 Nesse caso, a contribuição de Propp não elidiu a mais pulsante vida concreta, ponto de partida e de chegada em todo caso da doutrina das metamorfoses de Goethe, a matriz dessa teoria. Haroldo, por mais de uma razão, não dá continuidade a algo que no entanto não lhe escapa: "Essas 'representações abstratas', na concepção de Propp, são a projeção de determinados fenômenos históricos, por ele a seguir estudados do ponto de vista diacrônico (justamente na obra já mencionada)" (cf. Haroldo de Campos, op. cit., p.86n). 
11 Cf. Macunaima, ed. cit., p.70.

12 Logo no início do capítulo "Vei, a Sol” víamos o herói descansando da noitada no terreiro de Tia Ciata, numa ilhota da Baía de Guanabara, mais precisamente embaixo de uma palmeirinha guairô, até que um urubu aí encarapitado faz sujeira em cima dele (op. cit., p.65). A situação, embora reelaborada, já estava presente num dos relatos colhidos por Koch-Grünberg. Bem mais adiante, no capítulo final, que precede o Epílogo, desacorçoado da vida, Macunaíma resume por meio de um dito a consciência de seu grande infortúnio: "Quando urubu está de caipora o de baixo caga no de cima”. Mário (Macunaima, p.164). O que tínhamos visto no capítulo "Vei, a Sol” fora então algo como a pré-realização visual do provérbio enunciado bem depois.

13 Para retomar o vocabulário com o qual em "Parataxis" Adorno investiga um processo que de certo modo é inverso ao da rapsódia: a maior abstração (e a diminuição de "Realien") na lírica tardia de Hölderlin. Mas também se pode falar, a respeito de Macunaima, em parataxe. [Noten zur Literatur: Parataxis. Digitale Bibliothek Band 97: Theodor W. Adorno: Gesammelte Schriften, S. 9561 (vgl. GS 11, S. 459- 464)]

14 "Para a crítica da economia política", in Manuscritos econômico-filosóficos e outros textos escolhidos (Trad. de José Carlos Brunni, José Arthur Giannotti e Edgard Malagodi). São Paulo: Nova Cultural, 1987, p.19.

15 Alfredo Bosi, "Situação de Macunaíma”. In: Céu, Inferno. 3.ed. São Paulo: Duas Cidades/Editora 34, 2010, p.200.

16 Cf. Macunaima, p. 45.

17 Cf. op. cit., p.6.

18 Também numa pensãozinha (será a mesma?) na rua das Palmeiras moraram outros dois personagens de Mário: a tristonha professora de francês de "Atrás da catedral de Ruão", de Contos novos, e o inglesinho pobre e meio trickster - e um tanto alegórico - de Balança, Trombeta e Battleship.

19 Cf. Macunaima, p.47.

20 Fiz a análise específica do efeito "tangolo mangolo", que é também o nome de um tipo de parlenda, na segunda parte do ensaio (v. nota 1).

21 Antonio Candido, Recortes, São Paulo: Companhia das Letras, 2003, p.175.

22 Antonio Candido, "Um instrumento de descoberta e interpretação”, In: Formação da literatura brasileira. São Paulo: Livraria Martins, v.2, p.113ss.

23 Caio Prado Jr. Formação do Brasil contemporâneo. São Paulo: Brasiliense/Publifolha, 2000, p.289-92.

24 Ibidem, p.293-4. Ou, conforme a descrição célebre de Monteiro Lobato: "nosso progresso é nômade e sujeito a paralisias súbitas. [...] Emigra, deixando atrás de si um rastilho de taperas" ou de cidades mortas, percorridas no livro de contos de mesmo nome que o autor publicou em 1919.

25 Ibidem, p.4.

26 Ibidem, p.5.

27 Ibidem, p.4.

28 Ibidem, p.3.

29 Ver nota 2. 
30 Também aparece como elemento formal no "produtivismo" das enumerações e metamorfoses do livro, o que abordei em tese de doutoramento, defendida em 2006 na área de literatura Brasileira (do DLCV/USP), Macunaima: Enumeração e metamorfose, no qual já havia alguns dos materiais e reflexões do presente texto, como os relativos à enumerações e ao dinheiro. Alguns outros aspectos abordados por este artigo também estavam em germe em um dos relatórios enviados à Fapesp, "Entropia e trabalho", como contrapartida pela bolsa de pós-doutorado recebida entre 2008 e 2010.

31 "A divina preguiça”, A Gazeta. São Paulo, 3.9.1918, em Marta Rossetti Batista; Telê P. Ancona Lopez; Yone Soares Lima de. Brasil: 1. tempo modernista - 1917/29. São Paulo: IEB, 1972, p.182-3.

32 A esse respeito, cf., de André Gorz, "L'invention du travail”, in Metamorphoses du travail, Paris : Éditions Galilée (Folio/Essais), 1988, p.32-45. Quanto ao projeto de Delmiro Gouveia: “Segundo Arno Pearse, que lá esteve em 1921, tratava-se de '[...] uma cidade especialmente construida, onde as casas são espaçosas e a arquitetura e o plano da cidade modernos” (LIMA JÚNIOR, 1963, 206). Todos os operários da fábrica - com exceção dos rapazes solteiros sem família no local - moravam em casas de alvenaria, alugadas ou cedidas pela fábrica. //Coerente com a lógica que presidiu a concepção de núcleos fabris, Pedra foi concebida como um lugar do trabalho; como um espaço pensado para favorecer a produção de mercadorias e a reprodução de uma força de trabalho capacitada para o trabalho industrial e conduzida para respeitar o patrão e suas propriedades. [...] Pedra foi estruturada como um meio onde todas as circunstâncias se atrelavam à produção, onde tudo conspirava para converter o morador em indivíduo previdente, ordeiro, metódico, trabalhador e obediente. Tal esforço comportou ações voltadas para o controle do movimento das pessoas e dos contatos entre elas, para a supervisão do consumo, para a introdução de novas formas de perceber e gerir o tempo, para a promoção do lazer regrado e da educação, para a alteração de hábitos e dos cuidados com o corpo e com as casas. A fixação de normas determinando horários para as diversas atividades, prescrições morais, regras de higiene, proibição do consumo de bebidas e interdição de hábitos considerados impróprios e maneiras julgadas indecentes ou insolentes foram algumas das medidas adotadas. Neste projeto de construção de um novo trabalhador, estratégias de convencimento foram acompanhadas por medidas puramente repressivas." (Telma de Barros Correia, "Delmiro Gouveia: a trajetória de um industrial no início do século XX", disponível em <http://www.usp.br/pioneiros/n/arqs/tCorreia_dGouveia.doc>

33 "Um grande cearense", Os filhos da Candinha, São Paulo: Livraria Martins/Instituto Nacional do Livro, 1976, p.41-3.

34 Cf. op. cit., p.136.

35 Nietzsche, Segunda consideração intempestiva (trad. Marco Antonio Casanova). Rio de Janeiro: Relume Dumará, 2003, seção I.

36 Antonio Candido, "Dialética da malandragem". In: O discurso e a cidade. São Paulo: Duas Cidades, 1993.

37 Michael Löwy e Eleni Varikas, "A crítica do progresso em Adorno", Revista Lua Nova, São Paulo, n.27, set. 1992. E também, de Horkheimer, "Actualidade de Schopenhauer", Sociologica, Madrid, Taurus, 1971, p.176-7.

38 Cf. Max Horkheimer, "Vico y la mitología" (in Historia, metafísica y escepticismo (trad. Maria del Rosario Zurro), Madrid: Alianza Editorial, 1982, p.114-15. 
39 Walter Gebbard, "Die Erblast des 19. Jahrhunderts - Organismusdiskurs zwischen Goethes Morphologie und Nietzsches Lebensbegriff", in Faszination des Organischen (Org. H. Eggert, Erhard Schütz e Peter Sprengel). München: Indicium, 1995, p.1321, 31-6. Também se incluiria aí o método de uma ontofilogênese, como proposto por Haeckel (Spengler não é mencionado por Gebbard, mas poderia tranquilamente figurar no interior dessa corrente). Como observa o autor, "A redescoberta da concepção orgânica de Estado e sociedade ocorre em consequência da crítica à concepção do contrato social de Rousseau e de sua realização através da Revolução Francesa. A prioridade pertence aqui a Fichte [...]" e, em outro momento, citando outro comentador, com o qual um luckacsiano poderia estar de acordo: "O rancor contra a Revolução - que se autoriza invocando os reais custos desta e se alimenta do ressentimento contra o realismo social - invoca a natureza como bandeira nas visões de mundo em marcha" (Scheerer, apud op. cit., p.13 e 15). Também vale a pena conferir a observação de Hauser a propósito da evolução da ideia de morfologia: "Apesar de sua extremosa devoção, a concepção morfológica de história por Herder, que adota o aspecto cíclico da vida vegetal como seu ponto de partida e vê em toda parte o desenvolvimento da semente ao botão e à flor e da floração ao emurchecimento e à morte, é a expressão de uma perspectiva intrinsecamente pessimista do mundo que já contém o germe da teoria de Spengler do declínio da civilização" (cf. História Social da arte (trad. Alvaro Cabral). São Paulo: Martins Fontes, 1995, p.621). Para um estudo aprofundado da doutrina de Goethe e a concepção aí presente de forma e desenvolvimento natural, pertinente a sua reflexão estética, bem como para um apanhado do que seriam diferenças em relação a Herder e outros, veja-se, de Filomena Molder, O pensamento morfológico de Goethe. Lisboa: Casa da Moeda/Imprensa Nacional, 1995. Sobre o curioso uso dessa teoria por Benjamin na obra das Passagens (uma obra que, embora com resultados concretos muito diferentes dos de Spengler, dá importância análoga, por exemplo, à arquitetura, no caso, as passagens parisienses, lidas em suas transformações como "sucessão de formas históricas concretas do passado"), cf. p.183-99.

40 Carlos Eduardo Ornellas Berriel, Dimensões de Macunaima, filosofia, gênero e época. Campinas, 1987. Dissertação (Mestrado) - Universidade Estadual de Campinas. Campinas, 1987, p.71-110 (quanto à referência a Menotti, ver p.71).

41 "Spengler após o declínio", Prismas (trad. Jorge de Almeida e Augustin Wernet). São Paulo: Ática, 1988, p.67.

42 Veja-se a interessante apreensão de afinidades estruturais (princípio metodológico aliás fundamental no esquema morfológico) entre os sombrios subúrbios modernos e aqueles do Império Romano em declínio, no qual grassariam a especulação imobiliária e as consequências da expansão militar. No mesmo trecho, a observação de que enquanto magníficos túmulos de magnatas financeiros se semeavam ao longo da Via Apia, os cadáveres do povo eram arremessados junto com os de animais numa imensa vala comum (cf. Oswald Spengler, The decline of the west (trad. Charles Atkinson). New York: Alfred Knopf, 1926, p.35). Nessa comparação estrutural, a história aparece, portanto, como repetição (e o documento de cultura, como documento de barbárie), e Adorno está evidentemente interessado nessas imagens para apreender a asfixia do presente. O problema, diz ele em certa altura, é que há uma propensão mítica no próprio texto, "que se pode agarrar com a mão", e a repetição, ou o "eterno retorno do mesmo", aparece por fim desligada de causalidades concretas e diferenciadas - "em nenhum lugar o particular lhe revela algo que já não estivesse assegurado de antemão" 
(op. cit., p.55). Na crítica epistemológica à ideia de causalidade e a tudo que cheira a mecanicismo, Spengler aproveitaria para desacreditar o materialismo histórico.

43 Ibidem, p.50.

44 "O espirito, no sentido de uma autonomia ilimitada, só pode existir em conexão com a unidade abstrata do dinheiro" (op. cit., p.57), o que aprendemos, diga-se de passagem, com todo o Fausto II de Goethe.

45 Ibidem, p.58.

46 Susan Buck-Mors, The origins of negative dialectics. London; New York: The Free Press, 1977, p.48-49. Apud Susan Buck-Mors, op. cit., p.54-55, e Adorno, "Idee einer Naturalgeschichte", Digitale Bibliothek Band 1: Theodor W. Adorno: Gesammelte Schriften. Esse programa, como a própria comentadora observa, já estava presente, no caso de Adorno, desde fim dos anos 1920 e receberia expressão concreta numa fala de 1931 realizada na Sociedade Kantiana e não publicada em vida, "Ideia de uma história natural": "Apreender a história, em sua mais extrema determinação histórica, como se ela fosse natural, e apreender a natureza, lá onde ela aparece mais irredutível em si mesma, como sendo histórica". A conferência de 31 apresentava uma concepção dupla tanto de natureza quanto de história e não fazia segredo de suas maiores inspirações, ou seja, o conceito de "segunda natureza" da Teoria do romance de Lukács (mas, esclarece Buck-Mors, na verdade mais próximo da ideia de "fetiche" de História e consciência de classe) e o conceito benjaminiano de alegoria. Ambos permitiriam compreender como, no capitalismo, o mundo das mercadorias, embora criado pelo homem, "exercia um poder mítico sobre os homens, reminiscente de sociedades primitivas, nas quais a 'primeira natureza' dominava como uma força inexplicável. Como os fetiches primitivos, suas origens históricas tinha sido esquecidas; daí que os homens se submetiam a elas", tomados de uma mesma "ansiedade arcaica" (cf. "Idee einer Naturalgeschichte", op. cit.).

$47 \mathrm{Na}$ segunda parte do ensaio (ver nota 1), comento melhor o motivo da punição de Vei, a quem Macunaíma não teria sido leal e que constituiria para Gilda de Mello e Souza a razão das desventuras finais do herói.

48 Cf. "Parasitismo e degeneração", in A América Latina-males de origem [1903]. Rio de Janeiro: Centro Edelstein de Pesquisas Sociais, 2008, p.18-29, e especificamente p.22 (disponível em <www.do.ufgd.edu.br>). O autor que lhe fornece a teoria com a qual elabora a ideia de parasitismo das classes dominantes sul-americanas é Max-Nordau, autor do artigo, por ele citado, "Nouvelle théorie biologique du crime".

49 Francisco de Oliveira, Crítica da razão dualista/O ornitorrinco. São Paulo: Boitempo Editorial, p.2003. Cf. também, de Roberto Schwarz, o "Prefácio com perguntas" ao livro, op. cit. p.11-23.

50 T. Adorno, "Idee einer Naturgeschichte", Digitale Bibliothek, Gesammelte Schriften. Band I: Philosophische Frühschriften. S.345. Quanto à despedida de São Paulo, há, além da presença de Macário, de Álvares de Azevedo, possíveis ressonâncias do episódio do Gênesis (XIX, 14-26) relativo à fuga de Sodoma e Gomorra empreendida por Lot e a família, aos quais um dos anjos do Senhor tinha prevenido que não se voltassem para olhar a cidade em chamas, advertência ignorada pela mulher de Lot, transformada em estátua de sal. Numa espécie de inversão da imago, São Paulo é que é convertida em pedra, embora não se deixe de sugerir sua proximidade com as cidades amaldiçoadas, assim como a dupla função de Macunaíma no trecho, anjo ex- 
terminador e sobrevivente, que, no entanto, não se multiplicaria numa nova geração, como no mito bíblico.

51 Antonio Candido, “O poeta itinerante". In: O discurso e a cidade. São Paulo: Duas Cidades, 1993.

52 No caso de alguns tenentes, como L. C. Prestes, chocados com as condições de vida das várias populações que desconheciam antes de suas andanças que acabaram por totalizar $25.000 \mathrm{~km}$ do território, o comunismo aparecerá como o mais necessário e lógico. Quanto à frase referida, é de Lourenço Moreira Lima, secretário da Coluna (cf. Anita Leocádia, "A Coluna Prestes: uma proposta de trabalho", Revista de História, Universidade de São Paulo, n.118, p.52, 1985),. Entre os motivos que Prestes e outros integrantes do comando apresentaram para a retirada da Coluna: “[...] por um lado, o objetivo inicial de derrubar o presidente Bernardes perdera o sentido, na medida que já havia começado o quadriênio de Washington Luiz, trazendo consigo a esperança de uma possível anistia; por outro lado, principalmente para Prestes, já estava claro que a simples substituição de homens no poder nada resolveria. Era preciso buscar as causas sociais que determinavam a miséria em que vivia o povo brasileiro e que tanto impressionara a Prestes e alguns de seus companheiros. Para Prestes, que tinha o comando indiscutível da Coluna, chegara a hora de encerrar a Marcha e procurar nos livros a explicação para a situação em que se encontravam o país e o povo. Dessa explicação deveria resultar a nova solução a ser aplicada" (op. cit., p.53, grifos meus). Tanto quanto sei, essa versão é confirmada por outros historiadores e por ex-integrantes do movimento. Não custa lembrar, aliás, que o período de 1922-1926 transcorreu sob "permanente estado de sítio, em função dos levantes militares e da Coluna", esta noticiada pela imprensa nacional apenas em 1927 (cf. M. Camboa e L. Lyon [Mário Pedrosa e Lívio Abramo], "Esboço de uma análise da situação econômica e social do Brasil". In: Fulvio Abramo; Dainis Karepovs (Org.) Na contracorrente da história: documentos do trotskismo brasileiro 1930-1945. 2.ed. São Paulo: Sundermann, 2015, p.70n.

RESUMO - Qual o sentido dos infortúnios sucessivos de Macunaíma, sobretudo nos capítulos finais, quando, de posse do amuleto da sorte, nem por isso esta lhe sobrevém, mas ao contrário segue-se um processo cada vez mais acelerado de degradação entrópica? Umas das finalidades do artigo é mostrar, por um lado, o caiporismo do personagem como repetição estrutural, desenvolvido no âmbito da "morfologia da história" captada pelo livro, e, por outro, como esse azar permanente funciona como significante mítico de um permanente desamparo. Nesse sentido, o personagem é compreendido como uma síntese das experiências do vasto setor da população brasileira que Caio Prado Jr. chamou de inorgânico. Tal interpretação tem consequências para pensar a inadvertida mimese do real operada pela obra e a relação com a noção de progresso aí sugerida.

PALAVRAS-CHAVE: Macunaíma, Morfologia da história, Mito, Progresso, Entropia, Inorgânico.

ABSTRACT - What is the meaning of the successive misfortunes of Macunaíma, especially in the final chapters, when, in possession of the lucky amulet, neither fortune nor happiness come to him, but instead only an increasingly accelerated process of entropic degradation? One of the purposes of this article is to show, on the one hand, 
the character's bad luck as a structural repetition, developed within the scope of the "morphology of history" captured by the book, and, on the other hand, how this permanent misfortune functions as a mythical signifier of permanent helplessness. In this sense, the character is understood as a synthesis of the experiences of the vast sector of the Brazilian population that Caio Prado Jr. called inorganic. Such an interpretation has consequences for thinking the inadvertent mimesis of reality operated by the work and the relation with the notion of progress suggested therein.

KErWORDs: Macunaíma, Morphology of history, Myth, Progress, Entropy, Inorganic.

Priscila Figmeiredo é professora de Literatura Brasileira na USP e autora de Em busca do inespecífico, sobre Mário de Andrade. @-loydefigueiredo@gmail.com

Recebido em 26.1.2017 e aceito em 22.2.2017.

I Fculdade de Filosofia, Letras e Ciências Humanas, Universidade de São Paulo, São Paulo / São Paulo, Brasil. 